SAKAI SAMBAYAN — Jurnal Pengabdian kepada Masyarakat

\title{
PENINGKATAN KAPASITAS DAN PEMBERDAYAAN KELOMPOK PEREMPUAN PKK (PEMBINAAN KESEJAHTERAAN KELUARGA) MELALUI PENCIPTAAN USAHA STRATEGIS BERBASIS POTENSI DAERAH

\author{
(STUDI PADA KELOMPOK PEREMPUAN PKK DESA SUKAJAYA \\ LEMPASING KECAMATAN TELUK PANDAN KABUPATEN PESAWARAN)
}

\author{
Devi Yulianti ${ }^{*}$, Andi Windah ${ }^{2,}$ Mediya Destalia $^{3}$ \\ ${ }^{1} J u r u s a n$ Administrasi Publik Universitas Lampung, Bandar Lampung \\ Jl. Prof. Sumantri Brojonegoro No.1 Bandar Lampung 35145 \\ ${ }^{2}$ Jurusan Ilmu Komunikasi, Universitas Lampung, Bandarlampung \\ Jl. Prof. Sumantri Brojonegoro No.1 Bandar Lampung 35145 \\ ${ }^{3}$ Jurusan Administrasi Bisnis, Universitas Lampung, Bandarlampung \\ Jl. Prof. Sumantri Brojonegoro No.1 Bandar Lampung 35145 \\ Penulis Korespodensi : devi.yulianti@ fisip.unila.ac.id
}

\begin{abstract}
Abstrak
Tujuan umum yang dicapai dalam kegiatan ini adalah untuk menyebarluaskan hasil-hasil penelitian/kajian kepada masyarakat sebagai bagian dari upaya utuk memberdayakan dan meningkatkan kesejahteraan masyarakat, membangun kerjasama dan kemitraan dengan masyarakat sebagai perwujudan dan pengembangan kompetensi sosial di kalangan para dosen. Sedangakan tujuan khususnya adalah untuk meningkatkan kapasitas pengetahuan dan memberdayaan kelompok perempuan PKK Desa Sukajaya Lempasing Kecamatan Teluk Pandan Kabupaten Pesawaran untuk menciptakan usaha strategisnya berbasis potensi daerah sehingga usaha tersebut berkelanjutan dan dapat meningkatkan perekonomian perempuan serta bermanfaat bagi pembangunan desanya. Dalam pelaksanaan kegiatan akan menggunakan metode ceramah dan diskusi. Metode ceramah dan diskusi serta FGD di dalam ruangan yang digunakan untuk menyajikan materi. Adapun khalayak sasaran kegiatan seminar tentang penciptaan usaha strategis yang berkelanjutan dengan menggunakan analisis SWOT adalah kelompok perempuan yang termasuk dalam PKK. Tetapi kegiatan ini tidak menutup kemungkinan untuk pihak pengamat lain dalam mengikuti kegiatan.

Lokasi kegiatan pengabdian ini adalah di Desa Sukajaya Lempasing Kecamatan Teluk Pandan Kabupaten Pesawaran. Dengan adanya kegiatan pengabdian ini diharapkan dapat memberikan manfaat bagi khalayak sasaran yaitu memahami potensi daerahnya, memahami usaha strategis dan menciptakan langkah untuk memulai usaha tersebut. Hasil kegiatan pengabdian membawa peningkatan kemampuan dasar peserta. Peningkatan terendah sebesar 5\% dan peningkatan tertinggi sebesar 40\%. Rata-rata peningkatan adalah sebesar 17,5\%. Berdasarkan hasil dan evaluasi pelaksanaan pengabdian kepada masyarakat dapat disimpulkan beberapa hal sebagai berikut: 1). Kemampuan peserta pelatihan pada aspek kognetif dan afektif mengalami peningkatan dengan rata-rata sebesar 17,8\%., 2). Hasil evaluasi menunjukan peserta memiliki persepsi positif dan motivasi yang tinggi untuk menjalankan point penting dalam penciptaan usaha strategis berbasis potensi daerahnya, 3).Peserta menghendaki adanya pelatihan lanjutan.
\end{abstract}

Keywords: Peningkatan Kapasitas, Program Perencanaan Persalinan dan Pencegahan Komplikasi (P4K), Pelaksanaan Strategi

\section{Pendahuluan}

Indonesia merupakan negara kepulauan yang terdiri dari sekitar 17.504 pulau dengan panjang garis pantai kurang lebih $81.000 \mathrm{~km}$. Di sepanjang garis pantai ini terdapat wilayah pesisir yang relatif sempit tetapi memiliki potensi sumber daya alam hayati dan non-hayati; sumber daya buatan; serta jasa lingkungan yang sangat penting bagi kehidupan masyarakat. Potensi-potensi tersebut perlu dikelola secara terpadu agar dapat dimanfaatkan secara berkelanjutan. Wilayah pesisir secara ekologis merupakan daerah pertemuan 
antara ekosistem darat dan laut. Ke arah darat meliputi bagian tanah, baik yang kering maupun yang terendam air laut, dan masih dipengaruhi oleh sifat-sifat fisik laut seperti pasang surut, ombak dan gelombang serta perembesan air laut. Yang ke arah laut mencakup bagian perairan laut yang dipengaruhi oleh proses alami yang terjadi di darat seperti sedimentasi dan aliran air tawar dari sungai maupun yang disebabkan oleh kegiatan manusia di darat seperti penggundulan hutan, pembuangan limbah, perluasan permukiman serta intensifikasi pertanian, (Rudyanto, 2004:1).

Pesisir adalah wilayah yang unik, karena dalam konteks bentang alam, wilayah pesisir merupakan tempat bertemunya daratan dan lautan (Kay and Alder, 1999). Lebih jauh, wilayah pesisir merupakan wilayah yang penting ditinjau dari berbagai sudut pandang perencanaan dan pengelolaan. Transisi antara daratan dan lautan di wilayah pesisir telah membentuk ekosistem yang beragam dan sangat produktif serta memberikan nilai ekonomi yang luar biasa terhadap manusia. Sejalan dengan pertambahan penduduk dan peningkatan kegiatan pembangunan sosialekonomi, "nilai" wilayah pesisir terus bertambah. Konsekuensi dari tekanan terhadap pesisir ini adalah masalah pengelolaan yang timbul karena konflik pemanfaatan yang timbul akibat berbagai kepentingan yang ada di wilayah pesisir. Di masa lalu, paradigma pembangunan lebih memprioritaskan masyarakat perkotaan dan pertanian pedalaman, sedangkan masyarakat pesisir kurang diperhatikan. Sudah saatnya memang paradigma tersebut dirubah dengan memberikan perhatian yang sama terhadap masyarakat pesisir karena mereka juga adalah warga negara Indonesia. Konsekuensinya, justru masyarakat pesisir perlu mendapatkan perhatian khusus karena ketertinggalan mereka akibat paradigma masa lampau. Yang perlu dilakukan adalah pemberdayaan masyarakat pesisir. Karenanya, arah kebijakan sekarang ini untuk pemberdayaan masyarakat, umumnya bukan lagi ditekankan pada pembangunan (development) dalam arti memberikan barang atau uang kepada masyarakat, tetapi dengan pelatihan dan pendampingan selama beberapa waktu - perlu waktu bertahun-tahun agar masyarakat mempunyai kemampuan manajemen (pengelolaan).

Pembangunan menurut Sajogyo (1985) diartikan sebagai suatu proses yang menggambarkan adanya pengembangan, baik meliputi proses pertumbuhan (growth) ataupun perubahan (change) dalam kehidupan bersama (organisasi) sosial dan budaya. Hal ini tidak lain merupakan gambaran umum masyarakat luas (society). Sedangkan Tjokromidjojo (1979) mengemukakan bahwa pembangunan wilayah erat kaitannya dengan perencanaan pembangunan. Perencanaan pembangunan adalah suatu pengarahan penggunaan sumber-sumber pembangunan (temasuk sumber-sumber ekonomi) yang terbatas adanya, untuk mencapai keadaan sosial ekonomi yang lebih baik secara lebih efisien dan efektif. Selanjutnya Tjokromidjojo membedakan suatu perencanaan pembangunan, yaitu dipenuhinya berbagai ciri-ciritertentu serta adanya tujuan yang bersifat pembangunan. Adapun ciri dan tujuan dari perencanaan pembangunan adalah: 1). Perencanaan pembangunan mencerminkan dalam rencana untuk mencapai perkembangan sosial ekonomi yang tetap (steady social economic growth), 2). Usaha yang dicerminkan dalam rencana untuk meningkatkan pendapatan per kapita dan laju pertumbuhan ekonomi yang positif, 3). Usaha untuk mengadakan perubahan struktur ekonomi, 4). Perluasan kesempatan kerja, 5). Usaha pemerataan pembangunan yang seringkali disebut sebagai distributife justice. Pemerataan pembangunan ini ditunjukkan kepada pemerataan pendapatan antara golongan-golongan dalam masyarakat dan pemerataan pendapatan antara daerah-daerah dalam negara, 6). Adanya usaha pembinaan lembagalembaga ekonomi masyarakat yang lebih menunjang kegiatan-kegiatan pembangunan, 7). Peningkatan kemampuan membangun perlu dikembangkan bahwa tidak saja harus dihitung dari segi modal, tetapi juga harus dilihat dari segi pengalihan ketrampilan dan transfer teknologi, 8). Terdapatnya usaha secara terus menerus untuk menjaga stabilitas ekonomi.

Di Indonesia Pengelolaan Sumberdaya berbasis Masyarakat sebenarnya telah ditetapkan dalam Pasal 33 Undang-undang Dasar 1945 yang menyebutkan bahwa bumi dan air dan kekayaan alam yang terkandung di dalamnya dikuasai oleh negara dan dipergunakan sebesar-besarnya bagi kemakmuran rakyat. Ketentuan tersebut secara tegas menginginkan agar pelaksanaan penguasaan negara atas sumberdaya alam khususnya sumberdaya pesisir dan lautan diarahkan kepada tercapainya manfaat yang sebesar-besarnya bagi kemakmuran rakyat banyak, dan juga harus mampu 
mewujudkan keadilan dan pemerataan sekaligus memperbaiki kehidupan masyarakat pesisir serta memajukan desa-desa pantai.

Berdasarkan deskripsi tentang potensi Negara Indonesia dan cakupan wilayah pesisir serta pengelolaan wilayah yang berbasis komunitas atau masyarakat lokal serta hubungan tersebut dengan pembanguan di era otonomi daerah maka tim peneliti mengadakan pra riset di daerah Desa Sukajaya Kecamatan Teluk Pandan Kabupaten Pesawaran pada tangal 2 November 2017. Pada site visit yang akan menjadi tempat penelitian diperoleh keterangan bahwa, wilayah Desa Sukajaya Lempasing dipimpin oleh Kepala Desa yang berpendidkan sarjana yang baru dilantik pertengahan tahun 2017. Dalam catatan observasi penelit diperoleh keterangan bahwa susunan organisasi aparatur desa dan kelompok kerja masyarakat belum lengkap. Desa belum memiliki AD dan ART setiap organisasi atau kelompok yang dibentuk. Profil Desa Sukajaya Lempasing pun belum diperbaharui masih menggunakan dokumen lama di bawah lima tahun. Dibalik kekurangan kelembagaan yang dimiliki desa tersebut, daerah ini merupakan daerah pesisir yang menyimpan potensi yang seharusnya dioptimalkan pengelolaan sumber dayanya baik sumber daya alam maupun masyarakat serta kelembagaan untuk meningkatkan kesejahteraan atau nilai ekonomi suatu daerah. Desa ini memiliki kelompok masyarkat binaan seperti karang taruna, PKK, dan kelompok sadar wisata. Masyarakat di desa banyak yang bermata pencaharian sebagai nelayan dan pedagang. Karena lokasi merupakan daerah pariwisata maka mereka memiliki bisnis industri rumah tangga dengan produk seperti makanan olahan hasil laut seperti ikan asin, terasi, keripik dan kerajinan dari bahan kerang yang banyak dikelola oleh perempuan kelompok PKK. Akan tetapi dibalik tersedianya produk olahan industri rumah tangga tersebut, masyarakat Desa Sukajaya Lempasing merasa kesulitan untuk terus menyediakan sumber bahan mentah industrinya sehingga produk-produk tersebut terkadang tidak terus menerus dapat ditemukan di warung-warung atau toko-toko masyarakat. Kendala lainnya yang menjadi temuan awal tim peneliti adalah pengemasan produk olahan dan pemasaran industri rumah tangga.

\section{Bahan dan Metode}

Dalam pelaksanaan seminar menggunakan metode ceramah dan diskusi. Metode ceramah dan diskusi serta FGD (Focus Group Discussion) di dalam ruangan yang digunakan untuk menyajikan materi. Adapun materi yang akan diberikan adalah wawasan tentang wilayah pesisir, pengelolaan wilayah pesisir berbasis masyarakat, pemberdayaan masyarakat serta analisis SWOT untuk menciptakan usaha yang berkelanjutan, dengan rangkaian kegiatan sebagai berikut:

1. Penyampaian materi oleh fasilitator disertai kesempatan tanya jawab.

2. Diskusi kelompok, berguna untuk membahas persoalan-persoalan yang dihadapi dikaitkan dengan materi yang sedang dipelajari.

Evaluasi dalam kegiatan pelatihan ini dibedakan menjadi dua macam, yaitu:

a. Evaluasi Perubahan Pengetahuan

Evaluasi ini dilakukan dengan pre test dan post test. Selisih antara post test dan pre test dinyatakan dalam persen. Pertambahan tersebut kemudian dikelompokan dalam strata buruk, sedang dan baik.

b. Evaluasi Dampak

Evaluasi ini dilakukan sebelum kegiatan seminar berakhir Mekanismenya dengan membagikan kuesioner kepada sasaran pelaksana $\mathrm{P} 4 \mathrm{~K}$ dan dihitung berapa orang peserta yang telah menguasai materi dengan baik dalam pelaksanaan tugasnya.

\section{Hasil dan Pembahasan}

Secara umum diperoleh gambaran bahwa kegiatan "Peningkatan Kapasitas Dan Pemberdayaan Perempuan Kelompok PKK (Pembinaan Kesejahteraan Keluarga) Melalui Penciptaan Usaha Strategis Berbasis Potensi Daerah (Studi Pada Kelompok Perempuan PKK Desa Sukajaya Lempasing Kecamatan Teluk Pandan Kabupaten Pesawaran)" yang telah dilakukan, telah membawa peningkatan kemampuan dasar peserta. Peningkatan terendah sebesar 5\% dan peningkatan tertinggi sebesar $40 \%$. Rata-rata peningkatan adalah sebesar $17,5 \%$.

Peserta yang nilai dasarnya (pre test) cukup tinggi (sekitar 3 peserta) dengan kisaran nilai mulai dari 60-70, ternyata hasil post testnya pun menunjukkan peningkatan yang cukup signifikan. Setelah diurai oleh tim pengabdian, didapati bahwa hasil Pre-test peserta dengan hasil post test peserta yang terkategori tinggi memiliki korelasi dengan tingkat pendidikan dan pengalaman kerja. Oleh karena itu melalui kegiatan ini, peserta telah 
mendapatkan pemahaman yang utuh tentang penciptaan usaha strategis berbasis potensi daerah.

\section{Kesimpulan}

Berdasarkan hasil dan evaluasi pelaksanaan pengabdian kepada masyarakat dapat disimpulkan beberapa hal sebagai berikut:

1. Kemampuan peserta pelatihan pada aspek kognetif dan afektif mengalami peningkatan dengan rata-rata sebesar $17,5 \%$.

2. Hasil evaluasi menunjukan peserta memiliki persepsi positif dan motivasi yang tinggi untuk menjalankan point penting dalam penciptaan usaha strategis berbasis potensi daerahnya.

3. Peserta menghendaki adanya pelatihan lanjutan.

\section{Ucapan Terima Kasih}

Ucapan terimakasih terutama kepada

Universitas Lampung yang telah memberikan dana kegiatan pengabdian BLU Senior tahun 2018 dan segenap pihak yang membantu dalam mensukseskan kegiatan ini dari pembuatan proposal yaitu tim pengabdian dan beberapa mahasiswa bimbingan untuk turut berpartisipasi dalam kegiatan ini serta pihak Desa Sukajaya Lempasing Kabupaten Peswaran.

\section{Daftar Pustaka}

Kay, R. and Alder, J. (1999) Coastal Management and Planning, E \& FN SPON. New York

Rudyanto, Arifin, M.Sc, P.hd. Makalah disampaikan pada Sosialisasi Nasional Program MFCDP. September 2004.

Sajogyo, Pujiwati. 1985. Sosiologi Pembangunan. Fakultas Pasca Sarjana IKIP Jakarta. Jakarta.

Tjokroamidjojo, B. 1979. Perencanaan Pembangunan. Gunung Agung. Jakarta.

Undang-Undang Dasar 1945 Pasal 33. 